\title{
Linear Function Application: Enlightment to the Impact of Fuel Subsidy Removal in Nigeria
}

\author{
Abang I. S. *, Elufisan T.O., Okwubunne A. C. \\ National Centre for Technology Management, an Agency of the Federal Ministry of Science \& Technology, Obafemi Awolowo University, \\ Ile-Ife, Nigeria
}

\begin{abstract}
This paper adopts a linear function approach to analyse the effect of fuel subsidy removal on the value of Nigerian Naira and local production in the country. Data for about eight different periods where fuel hike occurred in Nigeria was used, and a mathematical model with the aid of a graph, was also developed to aid estimated calculation of Naira's value. We also deduced from this study that increase in fuel pump price has an adverse effect on the standard of living of the people, since fuel is essential for the transportation of major Nigerian commodities, such as Agricultural produce and other market product. The significant impact of the upsurge of petroleum pump price on the price of goods transport initiates this study; with the aim of checking its effect on the purchase value of naira. Though this study is totally neutral about the subsidy removal, its just to enlighten us on the topic and let viewers decide.
\end{abstract}

Keywords GDP, Subsidy, Data, Scarcity

\section{Introduction}

The strength of any nation could be determined by its economy stability and the constant growth rate of her GDP per capita. In the developed society scarcity of petroleum product is not a threat as several measures are in place to upturn such occurrences. The significance of energy in the build up of economic stability and advancement cannot be underemphasized, hence the need for the constant availability of energy supply[1,4]. Petroleum and other related product provide a huge mass of energy, which makes its availability as essential tool for nation building. Hence the continuous and consistent availability of petroleum product in the advanced countries cannot be excluded from the continuous trend of growth and development witnessed in such environment, particularly in building up indigenous capability for national development. The role indigenous technology plays in the build up of these nations can be factor to the availability of energy supply, particularly those derived from petroleum products. The impact of this can be significantly identified in the contribution of locally made product returns to countries' per capital GDP. Unlike the developed/economically-advanced countries the sub-Saharan Africa region where Nigeria belongs are faced with consistence fuel scarcity or scarcity of petroleum products. There were instances where the economic activities become stagnated due to the scarcity of petroleum product. This thus

* Corresponding author:

sunnyscott2010@yahoo.com (Abang I.S.)

Published online at http://journal.sapub.org/economics

Copyright (C) 2012 Scientific \& Academic Publishing. All Rights Reserved calls for a quick intervention. In a bid to averting the continual occurrence of this problem, Nigeria government have decided to intervene by deregulating the petroleum sector in the form of subsidy removal. The aim of the government for doing this is to minimize, if not totally eradicate petroleum scarcity.

Subsidy removal may however sound nice polite and beneficial, it is essential that there be a critical evaluation of the proposed mechanism for petroleum scarcity alleviation. Lessons from developed countries where this commodity has become readily available at all time reveals that subsidy removal is not a significant measure responsible for such achievement. China for instance still gives subsidy to her citizen on petroleum product and the fact available today showed that it still among the first five economy of the world that could boast of adequate petroleum product and economic stability[3]. It may be argued that most developed countries of the world had gone beyond subsidy, it is essential that Nigeria government look inward when formulating policies and designing program that has to do with her people, because internalizing is an essential tool for economic growth and development. No matter how good subsidy removal may look, the burden its short term effect will have on the masses should be a subject of concern. In a bid to addressing the attendant problems associated with the removal of subsidy this paper tried to look into the role increase in pump price will have on transportation, price of commodities and the current value of Naira.[1-2] The current living standard in Nigeria showed that about $60 \%$ of her citizen lives below one dollar per day, the removal of subsidy at such a period like this would exacerbate this identified scenario. This paper therefore made use of straight line 
graph/equation to enlighten us on the following issues: (i) application of linear function on real situation (ii) impact of subsidy removal on local production (iii) impact of subsidy removal on standard of living. An analysing tool (SPSS) was used to test for correlation between fuel pump price and transportation and we also check what the current purchase value of naira would be as a result of the subsidy removal.

\section{Literature Review}

Electricity is an essential tool which drives industrialization and hence a key factor in national economic growth and development. The generation of electricity is pivotal to the availability of electricity for energy consumption. There are several medium for the generation of electricity but the bulk of electricity generation in developing countries is through the use of petroleum product or fuel; Turbines are run on fuel powered generators. This implied the significance of fuel to national development. Thus whatever happens to fuel supply will has impact on economic growth and development.

It has been shown in the past that any significant increase in the fuel price often cause economic recession, such as witnessed in 1973 and 1979. One way in which the government had made fuel sufficiently available and affordable to the low-income earner is through subsidy. The introduction of subsidy indirectly promote economic growth and development as a result of the affordability of the price of goods which provides an enabling point for the middle class citizen to contribute significantly to the economy. Lesson from China shows how subsidy had contributed significantly to economic growth and development[3]. The success could be attributed to the affordability of energy and hence an increase in its demand. It therefore connotes that subsidy removal though will play significant role in nation building it is not the absolute resort to improve the economy. While it looks significantly important, there are other measures that could be adopted even without subsidy removal which would improve the economy significantly. And the presence of subsidy will play a pivotal role to the accomplishment of this measure as is being witnessed in china[3]. The removal of government benefit to the people in the form of subsidy will have a negative impact on the low to middle income earners. The middle income earners have been identified as the group of people in the nation, whose activities mostly drive economic growth and development. The high cost of commodities following the removal of subsidy will constitute an impediment to the good plan of the government associated with subsidy removal[5].

\section{Methodology}

The approach adopted in this study is the use of mathematical model in the form of a linear equation to investigate the impact of subsidy removal on the standard of living of the people and its long term economic effect. SPSS a statistical package was used to analyze the correlation between fuel pump price and transportation. The relationship between the two parameters was also used to analyse impact of subsidy removal on the purchasing power parity of the Naira.

Table 1. Conditional Probability table for Fuel price timeline in Nigeria some selected years

\begin{tabular}{|c|c|c|c|c|}
\hline S/N & $\begin{array}{c}\text { Year in } \\
\text { focus }\end{array}$ & $\begin{array}{c}\text { Fuel Price (F) } \\
\text { in naira }\end{array}$ & $\begin{array}{c}\text { Transport fare (T) } \\
\text { from Alapere to } \\
\text { Ojota in naira }\end{array}$ & $\begin{array}{c}\text { value of } \\
\text { naira to } \\
\text { US dollar }\end{array}$ \\
\hline 1 & 1992 & 5 & 0.5 & 9.91 \\
\hline 2 & 1993 & 3.25 & 0.5 & 17.30 \\
\hline 3 & 1994 & 11 & 1 & 22.33 \\
\hline 4 & 1998 & 15 & 2 & 21.89 \\
\hline 5 & 1999 & 20 & 5 & 21.89 \\
\hline 6 & 2001 & 22 & 10 & 103 \\
\hline 7 & 2005 & 52 & 30 & 132 \\
\hline 8 & 2007 & 75 & 40 & 120 \\
\hline 9 & 2008 & 65 & 40 & 115.50 \\
\hline 10 & 2012 & 141 & 80 & 159.45 \\
\hline
\end{tabular}

Source: NBS, 2009; Field survey, 2012

\subsection{Linear Application Explanation from a Real Situation}

The purpose of this section is to establish the relationship between the two variables (fuel pump price and transport fare), and their corresponding values gotten from the survey.

$$
\mathrm{F}(\mathrm{x})=\mathrm{mx}+\mathrm{c} \text {; }
$$

Which is similar to the equation of a straight line $y=m x+$ $\mathrm{c}$, which is a first degree equation.

$\mathrm{m}=\mathrm{N}$-economical factor,

$\mathrm{m}$ is the economical factor that determines the actual present value of Naira when considering 2 points of a given country's history.

$\mathrm{c}=$ intercept of fuel price and transport fare. Considering this we plot a graph of fuel price against transport fare.

it is represented mathematically as $m=$ change in transport fare/ change in fuel price current purchase value of naira $\left(\mathrm{C}_{\mathrm{P}} \mathrm{VN}\right)=$ change in transport fare / change in fuel price $\mathrm{x}$ any naira denomination. For example 2012 purchase value of one hundred naira is

$$
\mathrm{C}_{\mathrm{p}} \mathrm{VN}_{2012}=[(80-40) /(141-65)] \times 100
$$

Implies that $\mathrm{C}_{\mathrm{p}} \mathrm{VN}_{2012}=[40 / 76] \times \mathrm{N} 100=\mathrm{N} 52.60$, given from our model that $\mathrm{m}=52.60$ we can further deduce the value of $\mathrm{c}$ from the following equation

Given that $\mathrm{T}=\mathrm{mF}+\mathrm{c}$, such that if $\mathrm{c}=0$; change in $\mathrm{T}=$ $\mathrm{m}$ (change in $\mathrm{F}$ )

$$
\left(\mathrm{T}-\mathrm{T}_{1}\right)=\mathrm{m}\left(\mathrm{F}-\mathrm{F}_{1}\right)
$$

from the table1, we could deduce that $(\mathrm{T}-5)=52.6(\mathrm{~F}-0.5)$

$$
\mathrm{F}=52.6 \mathrm{~T}-26.3+5
$$$$
\mathrm{F}=52.6 \mathrm{~T}-21.3
$$

This implies that $\mathrm{c}=-21.3$

The negative sign gotten from the intercept shows that there was a point in time when fuel was practically gotten for free by Nigerians, that was actually before the first fuel hike in the country.

Therefore we can derive an equation for the economy of 
Nigeria which is $\mathrm{F}=52.6 \mathrm{~T}-21.3$. The value for the application of this equation is gotten from table1; it is a further explanation of the effect of fuel hike on the actual purchasing power of naira.

From the above table it was discovered that an increase in fuel price will eventually affect the exchange rate of Naira as against foreign currencies (especially dollar and pound). Considering the table it could be deduced that any change in fuel pump price would alter transport fare and therefore create an adverse effect on the standard of living and likewise the per capita income of the country.

\subsubsection{Quality of a Good Policy}

Here the paper tries to educate us on what is expected from a good policy.

When a government adopt a policy, it is essential that such policy satisfies the T-R-I-B-E scripture:

Transparency and Truth: it should be clear to everyone to read and understand without much difficulty.

Respect: when implementing the policy, the values of the country must be considered.

Integrity: the country's image should at all times be protected in implementing any policy.

Balance: the policy should not be made to favour a certain set /group of individuals.

Entrepreneurship: an implemented policy should be one that is beneficiary to every citizen of the country. It should not be made to satisfy the selfish interest of a few.

\subsubsection{Impact of Subsidy Removal on Local Production}

Here the study try to relate the change of fuel price on the local manufacturing industries.

Previous records have shown that any increase in the price of petroleum product automatically lead to an increase in the cost of transportation of both raw and finished product which in effect will lead to an increase in the cost of production for end user of such raw materials as well as increase in price of market products, hence, leaving the local industries to suffer in expense of their foreign counter part that could operate at a moderately low cost in their country. The in effect will promote large dependence on importation which may invariably have an adverse effect on national economic growth and development[1].

\subsubsection{Impacts of High Fuel Price on Economy/Standard of Living}

Increase in fuel price usually has serious macroeconomic effects throughout the globe, which may adversely affect economic growth and could lead to inflation and large swings in term of trade, with important balance of payments repercussions and inflation, and large swings in the terms of trade, with important balance of payments repercussions. This study reviews the immediate effects of the higher food and fuel prices on the balance of payments of net importers of these items, on overall inflation, and on poverty, both across and within countries. From table1 it is deduced that each time there is an increase in the pump price of fuel the value of naira depreciates, which in effect, affect the purchasing power of the Naira, hence, a higher level of financial instability among Nigerians. The upsurge in the pump price may lead to an increase in poverty level hence posing a challenge to the long term vision of reducing poverty In the country[6].

The study did a correlation on transportation and fuel price; the result gave a positive correlation (99.5\% correlation). Which indicate that an increase in transportation is directly proportional to increase in fuel price, which in turn affects the production and distribution of food items?

The effect of Adverse balance of payments of higher food and fuel prices remained limited until recently, but are now having larger effect, due to the current fuel pump prices.

\section{Recommendation}

Government needs to keep a formula based approach for determining fuel prices, so as to check exploitation by marketers.

There should also be some form of tax for importing of fuel into the country.

For subsidy removal to work alternative source to energy and transportation must be provided.

The government should create a policy that would encourage industrialization and provide a market environment which will encourage technological competitiveness that can drive economic growth and development.

\section{Conclusions}

This research has been able to show that an increase in fuel price would lead to subsequent increase in every commercial aspect, as a result having a negative impact on the standard of living of the citizen. Therefore the government should create a policy that would be able to ease the pain of his people and also support development, through lucidity.

\section{REFERENCES}

[1] Barakat, N. (2008), Impact of Removal of fuel subsidy on the manufacturing industry in Jordan. Retrieved on $20^{\text {th }}$ December 2011 from http://pdf.usaid.gov/pdf_docs/PNADM734.pdf

[2] Coady, D., El-Said, M., Gillingham, R., Kpodar, K., Medas, P., \& Newhouse, D. (2006). The magnitude and distribution of fuel subsidies: Evidence from Bolivia, Ghana, Jordan, Mali and Sri-Lanka. Retrieved on $2^{\text {nd }}$ of January 2012 from www.afdb.org/impact $\% 20$ of $\% 20$ High $\% 20$ Oil $\% 20$ Prices $\% 20$ -\%20Oil\%20and\%20Gas\%20in\%20Africa.pdf

[3] Dansie, G., Lanteigne, M. \& Overland, I. (2010). Reducing energy subsidies in China, India, and Russia: Dilemmas for decision makers, ISSN: 2071-1050. Retrieved on $3^{\text {rd }}$ January 
2012 from www.ndpi.com/journal/sustainability

[4] G-20, June 2010 Report: Analysis of the scope of energy subsidies and suggestions for the G-20 initiative pp 6. Retrieved on $2^{\text {nd }}$ of January 2012.

[5] Adenikinju, A. (2010). Energy pricing and subsidy reforms in Nigeria. Retrieved on $22^{\text {nd }}$ December 2011 from www.oecd.org/dataoecd/58/61/42987402.pdf

[6] Ter-Minassian, T., Allen, M. \& Johnson, S. (2008). Food and fuel prices - recent developments, macroeconomic impact, and policy responses. Retrieved on $20^{\text {th }}$ November 2011.

[7] National Bureau of Statistics (NBS), 2009 Report. Retrieved on $19^{\text {th }}$ December 2011 from www.nigeriastat.gov.ng 